\title{
Ciri Fizikokimia Filem Boleh Makan dan Filem Polietilena Bagi Ubi Keledek (Ipomoea batatas) Goreng
}

(Physicochemical Properties of Edible Films and Polyetylene Film on Fried Sweet Potatoes (Ipomoea batatas))

\author{
RIZAFIZAH OTHAMAN*, KAUSAR AHMAD FUAD, FARHAN MOHD NOR \& ROZIDA MOHD KHALID
}

\begin{abstract}
ABSTRAK
Penyelidikan dijalankan bagi menilai kesan penggunaan filem boleh makan dan filem polietilena (PE) sebagai bahan penyalut untuk ubi keledek (Ipomoea batatas) goreng. Kepingan ubi keledek disalut dengan lapisan filem boleh makan yang terdiri daripada $0.045 \mathrm{~g} / \mathrm{mL}$ selulosa metil (MC), $0.045 \mathrm{~g} / \mathrm{mL}$ selulosa hidroksipropil metil (HPMC) dan $0.16 \mathrm{~g} / \mathrm{mL}$ jagung zein (CZ) sebelum digoreng di dalam minyak sawit pada suhu 170-180 ${ }^{\circ} \mathrm{C}$ selama 3 min. Manakala ubi keledek juga disalut dengan filem tak boleh makan iaitu polietilena (PE) (nisbah PE kepada minyak 1:100 g/g) sebagai perbandingan. Ubi goreng tanpa salutan filem digunakan sebagai sampel kawalan. Ciri fizikokimia ubi goreng bersalut dianalisa. Keputusan menunjukkan semua filem melekat pada permukaan ubi setelah digoreng. Penggunaan filem CZ menjadikan permukaan filem licin dan wujud tanpa sebarang retakan. Filem MC pula memberi lapisan permukaan yang tidak rata tetapi menyaluti permukaan sampel dengan sekata. Tambahan pula, ubi bersalut MC menunjukkan peratusan lemak paling sedikit (13.6\%) selain kandungan kelembapan yang paling tinggi (17.5\%) berbanding sampel lain. Secara keseluruhan, MC merupakan filem yang terbaik untuk mengekalkan kelembapan bahan goreng dan mengurangkan penyerapan lemak.
\end{abstract}

Kata kunci: Hidroksipropil metil selulosa; jagung zein; polietilena; selulosa metil; ubi keledek

\section{ABSTRACT}

This study was carried out to evaluate the effect of edible film and polyethylene film (PE) on fried sweet potato (Ipomoea batatas) coating. Slices of sweet potato were coated with edible films which were $0.045 \mathrm{~g} / \mathrm{mL}$ methylcellulose (MC), 0.045 $\mathrm{g} / \mathrm{mL}$ hydroxypropyl methylcellulose (HPMC) and $0.16 \mathrm{~g} / \mathrm{mL}$ corn zein (CZ) before being fried at $170-180^{\circ} \mathrm{C}$ in palm oil for $3 \mathrm{~min}$. The sweet potato was also coated with inedible polyethylene (PE) film (ratio of PE to oil 1:100 g/g) as comparison. Fried potato without film coating was used as a control sample. The physicochemical characteristics of the coated sweet potato were analyzed. The results indicated that all films could be coated on the surface of the sweet potato. CZ film gave a smooth surface without any crack. MC film gave a non-uniform surface but coated the whole surface of the sample evenly. In addition, MC coated sweet potato showed the least fat percentage (13.6\%) and the highest moisture content $(17.5 \%)$ compared to other samples. Overall, MC is the best edible film to retain moisture and reduce the absorption of fat of fried products.

Keywords: Corn zein; hydroxypropyl methylcellulose; methylcellulose; polyethylene; sweet potato

\section{PENGENALAN}

Menggoreng merupakan kaedah yang popular dalam penyediaan makanan yang lazat dan cepat. Suhu yang tinggi ketika menggoreng memberikan tekstur dalaman yang lembut dan lembap di samping kerak yang rangup serta meningkatkan kesedapan makanan (Varela et al. 1988). Tambahan pula, makanan bergoreng mempunyai aroma serta rupa luaran yang menarik disebabkan oleh warna coklat keemasan yang terhasil. Warna yang terhasil selepas menggoreng adalah faktor utama dalam penerimaan pengguna terhadap produk goreng. Hasil warna makanan goreng boleh dikawal dengan kaedah memasak, keadaan minyak menggoreng, komposisi bahan campuran dan pemilihan bahan tambahan (Kulp \& Loewe 1990).

Filem boleh makan adalah sejenis filem yang digunakan untuk menyalut lapisan luaran makanan secara celupan atau semburan untuk memanjangkan hayat sesuatu produk yang juga boleh dimakan bersama-sama dengan makanan tanpa menyingkirkan filem tersebut. Filem boleh makan juga berfungsi sebagai pengganti dan penguat pada lapisan semula jadi untuk menghalang kehilangan kelembapan, selain dapat mengawal pertukaran gas penting seperti oksigen dan karbon dioksida yang terlibat dalam proses pernafasan (Attila \& William 2009). Tambahan pula, filem boleh makan memberikan kesterilan pada permukaan makanan dan mengelakkan kehilangan komponen penting yang lain.

Terdapat pelbagai jenis filem boleh makan yang digunakan secara meluas di dalam industri pemprosesan makanan. Antaranya ialah filem yang berasaskan hidrokoloid seperti selulosa metil (MC), selulosa hidroksipropil metil (HPMC) dan jagung zein (Maskat et 
al. 2005). Selain itu terdapat juga filem boleh makan yang berasaskan lipid. Lipid biasanya digabungkan dengan bahan-bahan pembentukan filem yang lain seperti protein atau polisakarida, sebagai zarah emulsi atau salutan pelbagai lapisan untuk meningkatkan rintangan kepada penembusan air (Mehyar et al. 2012). Filem resin yang polar adalah baik untuk menghalang gas $\mathrm{O}_{2}, \mathrm{CO}_{2}$ dan etilena. Bahan hidrofobik berasaskan lipid yang berpotensi untuk digunakan sebagai filem dan lapisan boleh makan termasuklah lilin semula jadi (karnauba, kandelila, bran beras dan lilin lebah), lilin berasaskan petroleum (parafin dan polietilena lilin), minyak mineral dan minyak sayursayuran, asetogliserol dan asid lemak, dan resin seperti Shellac dan resin kayu (Rhim \& Shellhammer 2005).

Masalah utama yang paling kerap berlaku bagi produk makanan bergoreng adalah lekatan. Masalah juga timbul terutamanya ketika memakan produk goreng bersalut kerana serpihan atau kepingan salutan tertanggal (Maskat et al. 2005; Suderman 1983). Selain itu, masalah lain yang sering terjadi ialah serapan minyak yang berlaku ketika proses menggoreng. Menurut Meyers (1990), fungsi selulosa hidroksipropil metil (HPMC) dan selulosa metil (MC) adalah sebagai penghalang serapan minyak kepada subtrat. Jagung zein (CZ) juga merupakan salah satu filem boleh makan yang diaplikasikan dalam penggorengan ubi kentang yang dapat memberi kesan penurunan serapan minyak sebanyak 28\% (Feeney et al. 1993). Dengan kata lain, filem boleh makan akan menghasilkan penurunan peratus lemak terhadap produk makanan bergoreng. Pengawalan suhu penggorengan juga penting. Suhu penggorengan yang normal adalah antara $182^{\circ} \mathrm{C}$ dan $193^{\circ} \mathrm{C}$. Jika suhu penggorengan terlalu rendah, akan berlakunya filem boleh makan atau salutan yang tidak masak dengan sempurna dan serapan minyak ke dalam produk makanan. Manakala jika suhu yang terlalu tinggi digunakan, hasil penggorengan akan menjadi gelap, berkerak dan hangus (Suderman 1983).

Di dalam kajian ini, beberapa filem boleh makan yang terdiri daripada selulosa metil (MC), selulosa hidroksipropil metil (HPMC) dan jagung zein digunakan untuk menyalut kepingan ubi keledek (Ipomoea batatas) dan dibandingkan dengan filem polietilena (PE) untuk melihat keberkesanan filem-filem tersebut terhadap ciri-ciri fizikokimia ubi keledek goreng.

\section{BAHAN DAN KAEDAH}

\section{BAHAN}

Ipomoea batatas iaitu ubi keledek dan minyak masak jenama Buruh keluaran Syarikat Lam Soon Sdn. Bhd. diperoleh dari Tesco Stores Puchong, Malaysia. Bahan untuk filem boleh makan ialah metil selulosa (MC), hidroksipropil metil selulosa (HPMC) dan jagung zein yang dibekalkan oleh Sigma-Aldrich (M) Sdn. Bhd. Bahanbahan untuk penyediaan larutan filem seperti isopropanol (J.T. Baker) diperoleh daripada Avantor, etanol, polietilena glikol, asid sitrik dan gliserin dari Sigma-Aldrich (M) Sdn. Bhd. Polietilena (PE) yang digunakan untuk perbandingan juga turut dibekalkan oleh Sigma-Aldrich (M) Sdn. Bhd.

\section{PENYEDIAAN LARUTAN MC DAN HPMC}

Kaedah menghasilkan larutan filem MC telah diperkenalkan oleh Park dan Chinnan (1995). Sebanyak 9 g MC dicampurkan secara berperingkat ke dalam $200 \mathrm{~mL}$ air pada suhu $45^{\circ} \mathrm{C}$ dan dikacau dengan menggunakan pengaduk bermagnet dengan kelajuan rotor $8 \mathrm{rpm}$ sehingga $\mathrm{MC}$ larut. $200 \mathrm{~mL}$ isopropanol dan $1 \mathrm{~mL}$ PEG dimasukkan ke dalam campuran filem sebagai agen pemplastik. Larutan menunjukkan $\mathrm{pH}$ neutral. Larutan filem yang sudah sebati dibiarkan semalaman. Penghasilan larutan filem HPMC menggunakan kaedah yang sama seperti penyediaan larutan MC.

\section{PENYEDIAAN LARUTAN CZ}

54 g CZ dicampurkan secara ansur-ansur ke dalam 325 $\mathrm{mL}$ etanol dan dikacau dengan menggunakan pengaduk bermagnet dengan kelajuan rotor $8 \mathrm{rpm}$ sehingga $\mathrm{CZ}$ larut. Kemudian $1 \mathrm{~g}$ asid sitrik berhablur kontang dicampurkan ke dalam larutan filem untuk merendahkan pH kepada pH7. $11 \mathrm{~mL}$ gliserin kemudiannya dimasukkan ke dalam larutan sebagai agen pemplastik. Larutan filem yang sudah sebati dibiarkan semalaman.

\section{PENYEDIAAN KEPINGAN UBI KELEDEK}

Ubi dibuang kulit dan dibersihkan menggunakan air untuk menghilangkan segala kotoran yang ada dan dibiarkan kering pada suhu bilik. Kemudian, ubi dipotong menjadi beberapa kepingan berukuran $1 \times 3 \mathrm{~cm}$ dengan ketebalan $0.5 \mathrm{~cm}$. Setiap kepingan mempunyai berat $1.6 \mathrm{~g}$.

\section{PROSES MENGGORENG UBI KELEDEK BERSAMA FILEM BOLEH MAKAN}

Kepingan ubi dicelup ke dalam larutan MC, HPMC dan $\mathrm{CZ}$ dan dibiarkan kering pada suhu bilik selama $5 \mathrm{~min}$. Apabila $500 \mathrm{~mL}$ minyak masak di dalam kuali kaca sudah mencapai suhu $170-180^{\circ} \mathrm{C}$, kepingan yang bersalut filem $\mathrm{MC}$ digoreng terlebih dahulu selama $3 \mathrm{~min}$ dan ditoskan. Minyak masak ditukar untuk gorengan kepingan ubi yang berbeza. Kepingan ubi yang sudah digoreng dan disejukkan ke suhu bilik disimpan di dalam plastik kedap udara dan dibekukan pada suhu $0-3^{\circ} \mathrm{C}$ sebelum analisis selanjutnya.

\section{PROSES MENGGORENG UBI KELEDEK BERSAMA FILEM POLIETILENA (PE)}

PE direndam di dalam minyak dengan nisbah PE kepada minyak 1:100 g/g. Minyak dipanaskan sehingga kesemua PE lebur. Selepas PE lebur, suhu ditetapkan pada $180^{\circ} \mathrm{C}$ dan kepingan ubi digoreng selama 3 min sebelum ditos. Kepingan ubi yang sudah digoreng dan disejukkan pada suhu bilik disimpan di dalam plastik kedap udara dan dibekukan pada suhu $0-3^{\circ} \mathrm{C}$ sebelum analisis selanjutnya. 


\section{PENCIRIAN}

Beberapa pencirian dilakukan terhadap kepingan ubi yang telah digoreng. Analisa morfologi sampel menggunakan mikroskopi imbasan elektron (SEM) model EVO MA 10 daripada Carl Zeiss. Pengukuran warna produk akhir pada tiga tempat berlainan sebanyak tiga replikasi menggunakan alat kromameter model CR400 jenama Minolta. Penentuan kandungan kelembapan dilakukan secara eksperimen dengan mengisar $10.0 \mathrm{~g}$ sampel ubi yang telah disaluti filem selama 3 min setiapnya, diletakkan dalam ceper aluminium dan dipanaskan pada suhu $150^{\circ} \mathrm{C}$ selama 12 jam. Pengiraan peratus kelembapan (\% kelembapan) sampel dikira berdasarkan (1):

$$
\% \text { kelembapan }=\left(\frac{\text { berat sampel asal }(g)-\text { berat sampel kering }(g)}{\text { berat sampel asal }(g)}\right) \times 100 \text {. }
$$

Akhir sekali, kandungan lemak ditentukan menggunakan kaedah pengekstrakan lemak soxhlet (model SOXTEC 2043 jenama FOSS). Heksana digunakan semasa kaedah soxhlet selama 1-2 jam pada suhu $140^{\circ} \mathrm{C}$ untuk melarutkan lemak pada sampel yang telah dikisar halus. Seterusnya, cecair yang tertinggal dalam kelalang dikeringkan pada suhu $100^{\circ} \mathrm{C}$ sehingga berat mencapai malar. Peratus kandungan lemak kasar (\% lemak) dikira berdasarkan (2):

$$
\% \text { lemak }=\left(\frac{\text { berat sampel soxhlet kering }(g)-\text { berat kelalang }(g)}{\text { berat sampel asal }(g)}\right) \times 10 \text {. }
$$

\section{Keputusan dan PerbinCANGan}

\section{WARNA UBI GORENG}

Rajah 1 menunjukkan hasil warna bagi setiap sampel ubi dan ubi goreng bersalut filem boleh makan dan filem PE. Daripada Rajah 1, salutan yang terdiri daripada salutan filem CZ menghasilkan warna yang lebih gelap dan produk yang lebih cerah pula terhasil daripada produk yang tidak disalut filem. Keadaan ini disebabkan oleh kandungan protein iaitu glutamina (21-26\%), leusina (20\%) dan prolina $(10 \%)$ di dalam larutan filem CZ (Shukla \& Cheryan 2001) berbanding MC dan HPMC yang merupakan selulosa eter. Hal ini kerana menurut Loewe (1993), warna produk bergoreng terhasil daripada penyerapan minyak, ketebalan salutan dan tindak balas pemerangan yang berlaku antara gula penurun dan sumber protein. Suhaila et al. (1998) pula mengatakan bahawa kehadiran protein menyebabkan peningkatan kadar pemerangan salutan disebabkan oleh kehadiran kumpulan amino yang terlibat di dalam tindak balas Maillard.

Jadual 1 pula menunjukkan parameter warna bagi setiap ubi goreng bersalut filem boleh makan dan filem PE daripada hasil analisis kromameter. Warna ubi goreng yang lebih gelap disebabkan oleh komposisi protein yang tinggi di dalam salutan filem juga dapat dilihat melalui nilai a (kemerahan) dan b (kekuningan) daripada jadual. Berdasarkan analisis kromameter ini, didapati nilai a dan b yang tinggi dihasilkan oleh salutan filem yang terdiri daripada komposisi CZ.

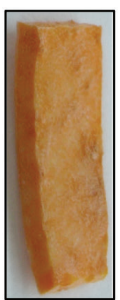

A

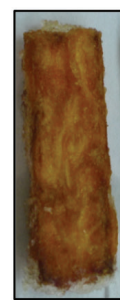

B

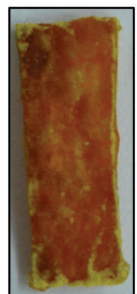

$\mathrm{C}$

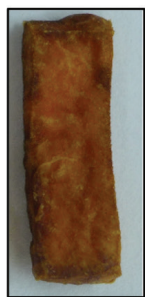

$\mathrm{D}$

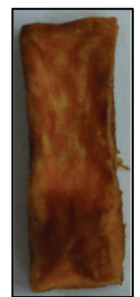

$\mathrm{E}$

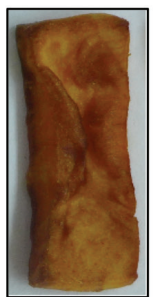

F

$$
\begin{aligned}
& \text { A : Ubi mentah } \\
& \text { B : Ubi goreng tanpa salutan } \\
& \text { C : Ubi goreng bersalut HPMC } \\
& \text { D : Ubi goreng bersalut MC } \\
& \text { E : Ubi goreng bersalut CZ } \\
& \text { F : Ubi goreng bersalut PE }
\end{aligned}
$$

RAJAH 1. Sampel kepingan ubi yang telah digoreng tanpa filem boleh makan, bersalut filem boleh makan dan bersalut PE

JADUAL 1. Nilai parameter warna bagi setiap ubi goreng bersalut filem boleh makan dan filem PE

\begin{tabular}{ccccccc}
\hline $\begin{array}{c}\text { Parameter } \\
\text { warna }\end{array}$ & Ubi & $\begin{array}{c}\text { Ubi goreng } \\
\text { tanpa filem }\end{array}$ & $\begin{array}{c}\text { Ubi goreng } \\
\text { bersalut filem } \\
\text { MC }\end{array}$ & $\begin{array}{c}\text { Ubi goreng } \\
\text { bersalut filem }\end{array}$ & $\begin{array}{c}\text { Ubi goreng } \\
\text { HPMC }\end{array}$ & $\begin{array}{c}\text { Ubi goreng } \\
\text { bersalut } \\
\text { filem PE }\end{array}$ \\
\hline L & 58.25 & 47.18 & 44.60 & 51.08 & 42.81 \\
a & 8.70 & 17.88 & 10.14 & 14.78 & 21.70 & 12.27 \\
b & 15.19 & 20.63 & 15.14 & 23.66 & 25.36 \\
\hline
\end{tabular}




\section{MORFOLOGI PERMUKAAN}

Rajah 2 menunjukkan mikrograf SEM bagi sampel ubi goreng pada $60 \times$ pembesaran. Dapat diperhatikan bahawa ubi yang belum digoreng mempunyai liang pada permukaan. Apabila ubi digoreng, sebahagian liang-liang tersebut telah tertutup. Hal ini menunjukkan bahawa semasa digoreng, liang-liang pada permukaan bertindak balas dengan medium minyak dengan membentuk satu lapisan. Namun begitu, liang-liang yang tidak tertutup menyebabkan penyerapan minyak yang banyak ke dalam sampel yang tidak mempunyai salutan filem. Ubi yang disalut filem HPMC dan salutan MC pula mempunyai permukaan yang sekata. Walau bagaimanapun, salutan MC dilihat menutupi liang secara lebih menyeluruh dengan sedikit ketidakrataan pada permukaannya. Menurut kajian yang telah dilaporkan oleh María et.al (2009), filem MC memberi struktur yang padat dengan ketiadaan liang walaupun larutan filem MC tidak dicampur dengan agen pemplastik.

Permukaan ubi goreng yang bersalut $\mathrm{CZ}$ pula adalah licin dan homogen berbanding yang lain. María et al. (2009) turut melaporkan bahawa tepung jagung akan memberi permukaan filem yang rata licin (tiada liang atau retak) dan homogen (tidak kelihatan pemisahan fasa), ditambah pula dengan kehadiran agen pemplastik. Namun begitu, permukaan yang licin tidak terlihat pada salutan filem PE yang mempunyai sifat pemplastik yang tinggi. Hal ini disebabkan oleh cara penyediaan larutan filem PE yang
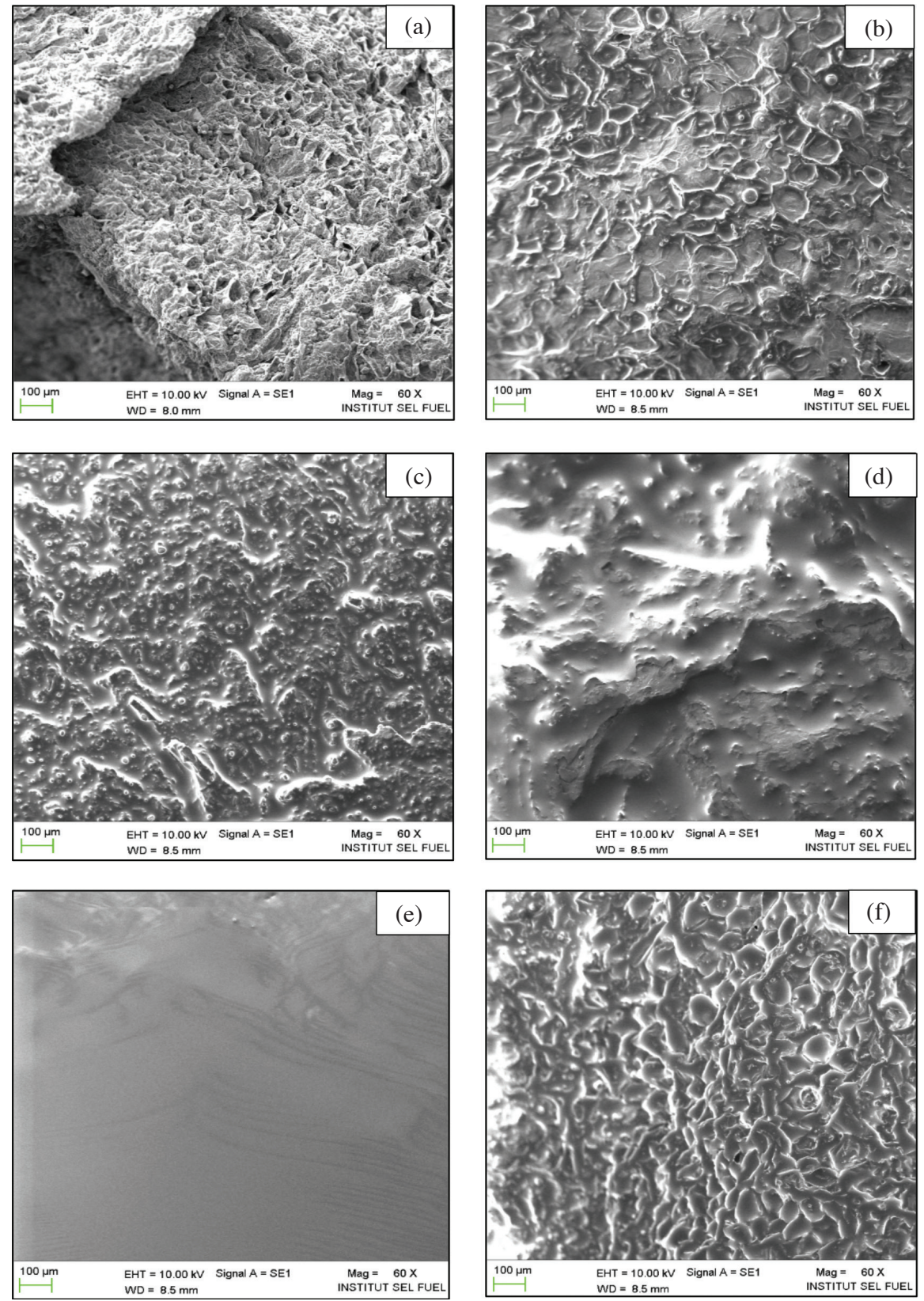

RAJAH 2. Mikrograf SEM bagi permukaan (a) ubi mentah, (b) ubi goreng tanpa filem, (c) ubi goreng bersalut filem HPMC, (d) ubi goreng bersalut filem MC, (e) ubi goreng bersalut filem CZ, dan (f) ubi goreng bersalut filem PE pada pembesaran 60x 
tidak sama seperti HPMC, MC dan CZ. PE yang melebur di dalam minyak panas tidak menyaluti permukaan sampel secara menyeluruh. Oleh itu, permukaan ubi goreng yang bersalut PE ini kelihatan sama seperti sampel goreng yang tiada salutan filem.

\section{ANALISIS KANDUNGAN LEMAK}

Analisis kandungan lemak dijalankan untuk menentukan sama ada kehadiran salutan filem pada permukaan ubi goreng dapat mengurangkan penyerapan minyak ke dalam ubi. Rajah 3 menunjukkan bagaimana filem boleh makan boleh berfungsi sebagai lapisan untk menghalang penyerapan minyak dan mengurangkan kehilangan kelembapan daripada sampel (Mallikarjunan et al. 1997).
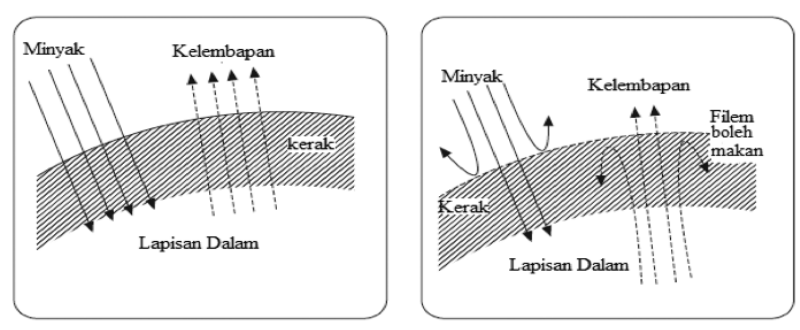

Sumber: Mallikarjunan et al. 1997

RAJAH 3. Konsep kesan filem boleh makan pada kelembapan dan pemindahan lemak semasa penggorengan rendaman minyak

Rajah 4 menunjukkan perbezaan peratusan kandungan lemak di dalam ubi tidak bergoreng serta ubi yang digoreng dengan salutan filem yang berbeza. Dapat diperhatikan bahawa kesemua filem boleh makan dan filem polietilena berkesan mengurangkan penyerapan minyak semasa proses penggorengan rendaman minyak dibandingkan dengan ubi yang tidak bersalut filem. Keputusan yang hampir sama juga dilaporkan oleh Mallikarjunan et al. (1997) yang menjalankan kajian terhadap kesan salutan boleh makan terhadap penggorengan rendaman minyak produk berkanji. Ubi yang disalut MC menyerap minyak paling sedikit iaitu sebanyak $13.63 \%$. Hal ini disebabkan oleh sifat keupayaan pengegelan terma berbalik yang ada pada molekul MC (Chidanandaiah et al. 2005). Ubi yang disalut filem $\mathrm{CZ}$ pula menunjukkan peratusan penyerapan yang paling tinggi $(22.6 \%)$ jika dibandingan antara filem boleh makan yang lain dan PE. Hal ini kerana CZ sendiri menyumbang kepada kehadiran minyak sebanyak 3.1\%. Tiada perbezaan yang signifikan dalam pengurangan penyerapan minyak antara ubi bersalut filem MC dan HPMC begitu juga dengan penyerapan minyak yang tidak jauh beza antara ubi bersalut filem CZ dan PE.

\section{KANDUNGAN KELEMBAPAN}

Perbandingan peratus kandungan kelembapan ubi dan ubi goreng bersalut filem boleh makan dan filem PE ditunjukkan dalam Rajah 5. Didapati bahawa ubi goreng

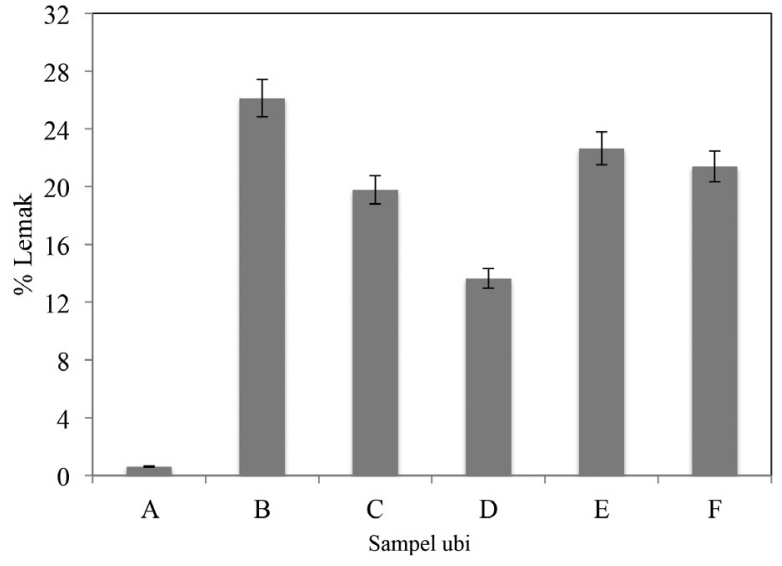

RAJAH 4. Peratusan kandungan lemak berdasarkan berat kering bagi ubi tidak bergoreng dan bergoreng bersama salutan filem boleh makan dan filem PE

yang bersalut filem MC mencatatkan peratus kandungan kelembapan yang tertinggi (17.5\%) manakala ubi goreng yang bersalut filem PE mencatatkan peratusan kelembapan yang terendah (10.8\%) antara semua filem yang dikaji. Peratusan kelembapan didapati berkadar songsang dengan peratusan kandungan lemak, kecuali pada ubi mentah. Ini bertepatan dengan konsep yang ditunjukkan pada Rajah 3 tentang fungsi lapisan filem boleh makan. Keseluruhannya, kandungan kelembapan adalah tinggi bagi ubi yang disalut dengan filem boleh makan dan filem PE. Tiada perbezaan yang signifikan antara ubi goreng bersalut filem MC dan HPMC.

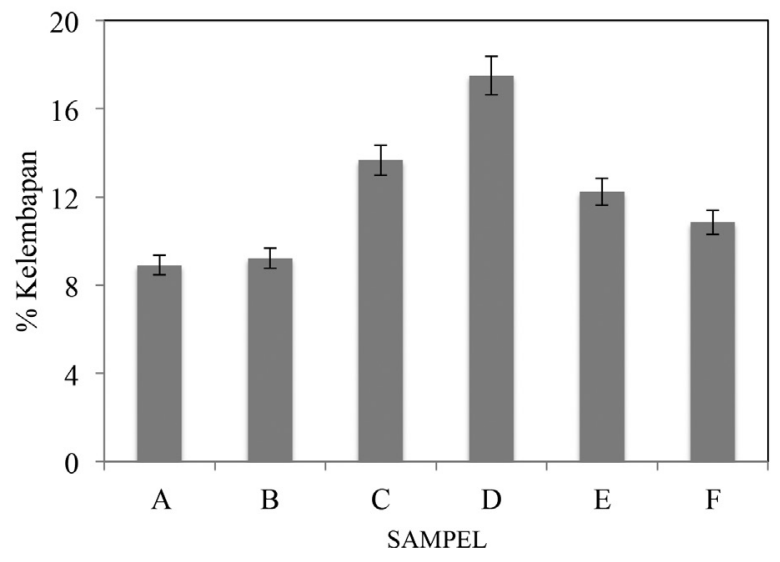

RAJAH 5. Peratusan kandungan kelembapan bagi ubi tidak bergoreng dan bergoreng bersama salutan filem boleh makan dan filem PE

Perbezaan peratusan kelembapan ini dipengaruhi oleh jenis filem salutan. MC dan HPMC adalah daripada hidrokoloid selulosa, CZ berasaskan protein, manakala $\mathrm{PE}$ adalah berasaskan plastik. Kumpulan metil pada molekul MC dan HPMC mengalami tindak balas antara molekul dengan molekul bersebelahan pada suhu melebihi suhu pemula pembentukan gel (IGT). IGT adalah suhu sekutuan 
antara molekul yang mula berlaku dengan cepat. Di atas paras IGT, kelikatan meningkat secara mendadak dengan peningkatan suhu, dengan bermulanya larutan gel (Meyers 1990). Julat suhu IGT untuk MC dan HPMC adalah antara $50-90^{\circ} \mathrm{C}$, bergantung kepada darjah penukargantian dan kepekatan. Lapisan gel yang terhasil ini dapat mengawal penukaran kelembapan antara sampel dan medium penggorengan.

CZ pula membentuk lapisan filem apabila bersentuh dengan permukaan sampel semasa penyalutan. $\mathrm{CZ}$ mengumpal kelembapan pada permukaan sampel dengan membentuk satu lapisan nipis yang termendak pada permukaan sampel. Menurut Wall dan Paulis (1978), ketidakbolehlarutan CZ adalah disebabkan oleh kandungan asid amino tak berkutub yang tinggi dan tindak balas protein melalui ikatan hidrogen dengan glutamina. Tambahan pula, ikatan hidrogen terbentuk di dalam matriks filem semasa penyejatan pelarut alkohol (Pomes 1971). Kemungkinan lain yang menjadi faktor penyumbang kepada rendahnya peratusan kelembapan sampel salutan filem CZ berbanding filem MC, HPMC dan PE adalah disebabkan oleh filem salutan CZ mengandungi gliserol berplastik, manakala filem larutan HPMC dan MC mengandungi polietilena glikol (PEG) berplastik. Gliserol adalah lebih hidrofilik berbanding PEG, menjadikan gliserol penghalang kelembapan yang lemah berbanding PEG (Park et al. 1994). Perbandingan peratusan kandungan kelembapan antara $\mathrm{CZ}$ dan PE pula menunjukkan PE lebih rendah peratusannya (10.8\%) kerana PE sendiri mempunyai sifat pemplastik yang tinggi. Oleh itu, keupayaan menghalang kelembapan salutan filem menurun.

Gambel et al. (1987) melaporkan bahawa semasa penggorengan, jumlah minyak yang masuk ke dalam sampel adalah berkadar dengan jumlah kehilangan air daripada sampel tersebut. Minyak akan menggantikan ruang-ruang yang ditinggalkan oleh air. Selain itu, ia juga akan meresap masuk ke dalam sampel apabila sampel dikeluarkan daripada alat penggoreng disebabkan keadaan vakum yang wujud akibat kondensasi stim. Hasil kajian ini adalah bercanggah dengan pernyataan Bhatt dan Bhattacharya (2001). Mereka melaporkan bahawa semasa proses penggorengan, stim yang terbentuk akibat suhu yang tinggi tidak dapat keluar daripada bahagian dalam sampel dengan mudah akibat pembentukan struktur keras pada permukaan sampel. Dengan itu, liang-liang yang telah wujud bersatu untuk membentuk vakuol yang besar dengan membenarkan stim keluar dari produk secara perlahanperlahan dan berterusan dan kemudiannya barulah minyak boleh diserap ke dalam liang-liang setelah stim keluar. Ini menunjukkan kehilangan kelembapan dan kemasukan minyak ke dalam sampel tidak berlaku pada kadar yang sama.

Pendapat yang dikemukakan oleh Pinthus et al. (1993) juga didapati bercanggah dengan Gambel et al. (1987). Menurut Pinthus et al. (1993), teori pertukaran jumlah yang sama antara air dengan minyak menunjukkan bahawa teori ini tidak dapat ditepati lalu membuat kesimpulan dan mencadangkan terdapat faktor-faktor lain yang perlu dikaji selain mekanisme penggantian air ini. Selain itu, kajiannya juga membuktikan bahawa tiada perkaitan yang berkadar terus antara penyerapan minyak dan pengeluaran air semasa penggorengan dan mencadangkan ia memerlukan mekanisme yang lebih kompleks dan bukan hanya bergantung kepada teori penggantian air oleh minyak yang mudah (Pinthus et al. 1997). Namun demikian, setiap keputusan kajian dan pendapat yang diberikan adalah bergantung kepada jenis sampel yang dikaji dan perlu mengambil kira kandungan lemak sedia ada di dalam sampel yang turut cair dan meresap keluar daripada sampel semasa proses penggorengan.

\section{KESIMPULAN}

Analisis kimia menunjukkan bahawa penggunaan salutan filem boleh makan dan filem PE ke atas produk goreng dapat mengurangkan peratus kandungan lemak di dalam ubi. Peratus kandungan lemak yang paling sedikit ditunjukkan oleh salutan filem MC iaitu sebanyak $13.63 \%$. Ubi goreng tersalut filem MC juga memiliki peratusan kelembapan tertinggi berbanding salutan filem yang lain. Salutan filem CZ memberi permukaan produk yang rata licin (tiada liang atau retak) dan homogen (tidak kelihatan pemisahan fasa). Secara keseluruhannya dapat disimpulkan bahawa salutan filem MC adalah filem yang terbaik dalam menghalang penyerapan kandungan lemak dan mengekalkan kandungan kelembapan di dalam produk goreng walaupun warna akhir produk salutan filem $\mathrm{CZ}$ memberi ciri fizikal yang lebih menarik.

\section{RUJUKAN}

Attila, E.P. \& William, O. 2009. Edible films and coating: why, what, and how? Dlm. Embuscado, M.E. \& Huber, K.C. (pnyt.). Edible Films and Coatings for Food Applications. New York: Springer. hlm. 1-5.

Bhatt, K.K. \& Bhattacharya, S. 2001. Deep fat frying characteristic of chickpea flour suspensions. International Journal of Food Science \& Technology 36: 499-507.

Chidanandaiah Keshri, Sanyal, M.K., Kotwal, S.K. \& Sudhan, N.A. 2005. Quality changes in enrobed/coated products during storage. Indian Food Industry 24: 57-61.

Feeney, R.D., Haralampu, S.G. \& Gross, A.T. 1993. Potato and their food products coated with edible oil barrier films. U.S. Patent: 5, 217, 73 .

Gambel, M.H., Rice, P. \& Selman, J.D. 1987. Relationship between oil uptake and moisture loss during frying oil potato slice from c.v. Record U.K. tubers. Journal Food Science 22: $233-241$

Kulp, K. \& Loewe, R. 1990. Batters and Breadings in Food Processing. St. Paul: American Association of Cereal Chemists.

Loewe, R. 1993. Role of ingredients in batter systems. Cereal Foods World 38(9): 673-677.

Mallikarjuna, P., Balasubramaniam, V.M., Chinnan, M.S. \& Phillips, R.D. 1997. Edible coatings for deep-fat frying of starchy products. Journal of LWT-Food Science and Technology 30: 709-714. 
María, A.G., Adriana, P., Miriam, N.M. \& Noemí, E.Z. 2009. Characterization of starch and composite edible films and coatings. Dlm. Embuscado, M.E. \& Huber, K.C. (pnyt.). Edible Films and Coatings for Food Applications. New York: Springer. hlm. 169-209.

Maskat, M.Y., Yip, H.H. \& Mahali,H.H. 2005. The performance of a methyl cellulose-treated coating during the frying of a poultry product. International Journal of Food Science and Technology 40: 811-816.

Mehyar, G.F., Al-Ismail, K., Han, J.H. \& Chee, G.W. 2012. Characterization of edible coatings consisting of pea starch, whey protein isolate, and Carnauba wax and their effects on oil rancidity and sensory properties of wal-nuts and pine Nuts. Journal of Food Science 77(2): E52-E59.

Meyers, M.A. 1990. Functionality of hydrocolloids in batter coating system. Dlm. Kulp, K. \& Loewe, R. (pnyt). Batters and Breadings in Food Processing. St Paul: American Association of Cereal Chemists. hlm. 117-142.

Park, H.J. \& Chinnan, M.S. 1995. Gas and water barrier properties of edible films from protein and cellulosic materials. Journal of Food Engineering 25: 497-507.

Park, H.J., Bunn, J.M., Weller, C.L., Vergano, P.J. \& Testin, R.F. 1994. Water vapor permeability and mechanical properties of grain protein-based films as affected by mixtures of polyethylene glycol and glycerin plasticizers. Transactions of ASAE 37: 1281-1285.

Pinthus, E.J., Singh, R.P., Rubnov, M. \& Saguy, I.S. 1997. Effective water diffusivity in deep-fat fried restructured potato product. International Journal of Food Science \& Technology 32: 235-240.

Pinthus, E.J., Weinberg, P. \& Saguy, I.S. 1993. Criterion for oil uptake during deep-fat frying. Journal Food Science 58(1): 204-205, 222

Pomes, A.F. 1971. Zein. Dlm. Mark, H.F., Gaylord, N.G. \& Bikales, N.M. (pnyt). Encylopedia of Polymer Science and Technology: Plastic, Resins, Rubber, Fibers. New York: Interscience Publishers. hlm. 125-132.
Rhim, J.W. \& Shellhammer, T.H. 2005. Lipid-based edible films and coatings. Dlm Han, J.H. (pnyt). Innovations in Food Packaging. London: Elsevier.

Shukla, R. \& Cheryan, M. 2001 .Zein: The industrial protein from corn. Industrial Crops and Products 13: 171-192.

Suderman, D.R. 1983. Application of batters and breadings to seafood. Dlm. Suderman, D.R. \& Cunningham, F.E. (pnyt). Batter and Breading. Connecticut: AVI Publishing Company. Inc. hlm. 1-14.

Suhaila, M., Norhasimah, A.H. \& Mansoor, A.H. 1998. Food components affecting the oil absorption and crispness of fried batter. Journal of the Science of Food and Agriculture 78: 39-45.

Varela, G., Bender, A.E. \& Morton, I.D. 1988. Current Facts about the Frying Food. Chichester: Horwood Limited.

Wall, J.S. \& Paulis, J.W. 1978. Corn and sorghum grain proteins. Dlm. Pomeranz, Y. (pnyt). Advances in Cereal Science and Technology. St Paul: American Association of Cereal Chemists. hlm. 135-219.

Pusat Pengajian Sains Kimia dan Teknologi Makanan

Fakulti Sains dan Teknologi

Universiti Kebangsaan Malaysia

43600 Bangi, Selangor Darul Ehsan

Malaysia

*Pengarang untuk surat-menyurat; email: rizafizah@ukm.edu.my

Diserahkan: 13 Jun 2016

Diterima: 17 Oktober 2016 